\title{
The Fixed-Date \\ Election Law: \\ Constitutional \\ Convention or \\ Conventional \\ Politics?
}

\section{Robert E. Hawkins ${ }^{\star}$}

On September 17, 2009, Justice Michel Shore of the Federal Court of Canada refused a request from Duff Conacher and Democracy Watch, applicants, to declare "that a constitutional convention exists that prohibits a Prime Minister from advising the Governor General to dissolve Parliament except in accordance with Section 56.1 of the Canada Elections Act." That section, known as the "fixed-date election law," received Royal Assent on May 3, 2007. The court application was triggered by Prime Minister Harper's September 7, 2008 request to Governor General Michaëlle Jean asking her to dissolve Parliament and call a "snap" election. The resulting election, held on October 14, 2008, returned another Conservative minority government, albeit a stronger one.

The fixed-date election law states that it does not affect the powers of the governor general to dissolve Parliament at his or her discretion. It then goes on to provide that "each general election must be held on the third Monday of October in the fourth calendar year following polling day for the last general election." 2 Justice Shore's decision leaves unaltered the existing convention that the governor general must accept the prime minister's recommendation to dissolve Parliament except when, immediately following a general election, there exists another potential government able to command the confidence of the House of Commons. This convention ensures responsible government.
Duff Conacher and Democracy Watch unsuccessfully appealed Justice Shore's decision. In brief reasons given from the bench on May 25, 2010, the Federal Court of Appeal upheld that the lower court's conclusion that there was no new constitutional convention on fixed election dates. The appeal court said that Justice Shore's finding on this point was "amply supported by the evidentiary record."

Conventions are unwritten rules that ensure the constitution operates in accordance with the generally accepted practices governing parliamentary democracy. They modify the constitution's written rules and, in so doing, prevent the constitution, which is difficult to amend, from becoming out-of-step with the times. Breaches of convention are penalized in the political arena by the electorate, rather than in the legal arena by the courts. A convention must embody a constitutional principle, it must command "unquestioned acceptance," ${ }^{4}$ and it must be sufficiently precise as to be identifiable and workable. ${ }^{5}$

Several preliminary points should be made concerning proof of a constitutional convention. First, declaring a constitutional convention to exist is a serious business. The elaboration of a new constitutional convention has the same effect as adopting a formal constitutional amendment. The emergence of a new convention allows the formal constitutional amendment process to be circumvented. While the 
standard for proving the existence of a constitutional convention is the civil "balance of probabilities" standard, the evidence adduced for meeting that standard must be commensurate with the occasion, that is, it must be clear, cogent and persuasive. ${ }^{6}$ This is important to keep in mind when evaluating statements from the politicians who debated the adoption of the fixed-date election law.

Second, either the fixed-date election law is an unconstitutional interference with the powers of the governor general - something which it expressly purports not to be - or it leaves the prime minister's discretion to advise dissolution unchanged, in which case there is no new convention. ${ }^{7}$ There are no other possibilities. Rob Nicholson, then Leader of the Government in the House of Commons and Minister Responsible for Democratic Reform, testified accurately on this point before the Standing Committee on Procedure and House Affairs prior to the passage of the fixed-date election law. He stated:

\section{Under the rules and conventions of responsible government, the Governor General's power to dissolve Parliament has to be exercised on the advice of the Prime Minister. The Governor General's legal power under the Constitution and the exercise of that power on the advice of the Prime Minister are fundamentally and in- separably linked. If one limits the Prime Min- ister's ability to advise, one risks constraining the Governor General's powers in a way that would be unconstitutional. ${ }^{8}$}

Third, as indicated above, a convention must be sufficiently precise as to be identifiable and workable. The fixed election law, which the applicants submit establishes a new convention, ${ }^{9}$ is neither precise nor workable. For one thing, the law simply sets a fixed election date; it does not prohibit the prime minister from recommending dissolution prior to that date. ${ }^{10}$ For another, the law does not make an exception for dissolution when the government loses the confidence of the House prior to the fixed election date. In order to fill in these gaps, the applicants suggest that the law be interpreted in light of a new convention limiting the right of the prime minister to seek dissolution except in the case of a loss of confidence in the House. ${ }^{11}$ It is difficult, however, for the applicants to argue that the law establishes a convention of a fixed election date, while at the same time relying on just such a convention to fill the critical gaps in the law. This is indeed a dog in search of its tail.

Fourth, it is questionable whether the existence of a fixed-date election convention is justiciable. Although the Supreme Court of Canada was prepared to rule on the existence of conventions in the Patriation Reference ${ }^{12}$ and the Quebec Veto Reference, ${ }^{13}$ the Court may have been enticed onto this political terrain because the very survival of the country was at stake. Those extraordinary circumstances are not present in the litigation over the existence of a fixed-date election convention. Further, there is danger that in ruling on such a convention, a court could become instrumental in generating, ex post facto, the kind of general acceptance that should be a pre-condition for establishing the convention. Also, a ruling that a fixed-date election convention exists could eventually require the courts to define the circumstances in which a government is deemed to have lost the confidence of the House - a matter that is political in nature and which, if a court becomes involved, could threaten the separation of powers between the judicial branch on the one hand and the legislative and executive branches on the other. ${ }^{14}$ Finally, a declaration confirming the existence of a fixed-date election convention would have no legal effect. It would invalidate neither the results of the 2008 election nor the work of the Parliament returned in that election, although it might cast a political shadow over the legitimacy of that work. Put simply, the declaration being sought is in relation to a matter that is legally moot.

In deciding that a convention of fixed election dates did not exist, Justice Shore applied the Jennings test, as adopted by the Supreme Court of Canada in the Patriation Reference. He stated: "That test consists of three questions: first, what are the precedents; second, did the actors in the precedents believe that they were bound by a rule; and third, is there a reason for the rule?"15 The great merit of the Jennings test is its rigour. A constitutional norm is proven to exist when those charged with the operation of the constitution feel bound by past practice (a 
temporal dimension), bound by their own belief that they are bound (a normative dimension), and bound by the reason for the norm (a rational dimension). Applying these criteria, there is little danger that purely political choices, or choices made out of a desire to circumvent the exigencies of the formal constitutional amendment process, will qualify as conventions.

Jennings does not require that all three criteria be met in order to prove the existence of a convention: "A single precedent with a good reason may be enough to establish the rule. A whole string of precedents without such a reason will be of no avail, unless it is perfectly certain that the persons concerned regarded them as bound by it."16 In other words, the key to establishing a constitutional convention is that the "persons concerned," the actors in the precedents, consider themselves "bound" to follow the rule. They must feel that they have no choice but to follow the norm, either because there is a compelling precedent from the past or because there is a good constitutional reason for the norm. In the Quebec Veto Reference, the Supreme Court held that the actor's belief that he or she had no option but to follow the norm is the most important sign of the existence of a convention. This feeling of obligation, because of its normative force, is what distinguishes "a constitutional rule from a rule of convenience or from political expediency." ${ }^{17}$

Professor Andrew Heard, in his critique of the Conacher decision, suggests that Justice Shore failed to consider adequately an alternative model in concluding that a fixed election convention did not exist. ${ }^{18}$ Heard maintains that an explicit agreement between politicians on the operation of the constitution can give rise to a general expectation amongst constitutional experts that a new convention has been brought into existence. This expectation will be evidenced by statements made by members of the constitutional community, including constitutional scholars and journalists. Applying this model, Heard argues that the agreement of all political parties to pass the fixed-date election law created a general expectation amongst constitutional experts, and so a convention, that the prime minister would not recommend dis- solution prior to the date set in the legislation, unless the government were to lose the confidence of the House.

Apart from not having been sanctioned by the Supreme Court, Heard's alternative model differs from the Jennings model on three counts. First, it looks to an "explicit agreement," as opposed to a past precedent, as the source of a constitutional convention. Second, it draws its normative or binding power from the "general expectations" raised by that explicit agreement rather than from the beliefs created by precedent or the reasons for the convention. Third, it identifies the persons concerned as the "broader constitutional community" rather than the relevant actors charged with making the constitutional decisions in the precedents.

The contention here is that the three criteria which make up this alternative model - explicit agreement, general expectations, and constitutional community - fail to distinguish a constitutional imperative from a simple exercise in political expediency. Each one of the three criteria in the alternative model obscures this crucial distinction, and therefore raises a serious problem of constitutional principle. Moreover, each of them raises practical issues, that is, problems in applying the criteria that would recur in future constitutional disputes. The remainder of this article considers the three suggested departures from the Jennings model in turn.

First, contrasting explicit agreements with past precedents misunderstands the issue. For Jennings, and for us, the issue is not the source of the norm in question, but rather whether the relevant actors feel bound by the norm to operate the constitution in a given manner. Are they obliged by what they regard as a constitutional imperative to proceed in a particular way or do they have a political choice with respect to the matter? If an explicit agreement were irrevocable, these actors might well believe that it bound them just as much as a chain of precedent, or an incontestable rationale, would bind them. The problem is that explicit agreements are normally subject to reconsideration, renegotiation and change, whereas past precedents or incontestable rationales are immutable. As a result, an explicit agreement provides less convincing 
proof that the relevant actors feel irrevocably bound than would an unchanging precedent or an unanswerable rationale. This difficulty is compounded by the need to demonstrate the binding force of the norm with clear and cogent evidence if the norm is to rise to the level of a convention. ${ }^{19}$

There is also a practical problem with the explicit agreement approach in the fixed-date election case. Simply put, no such agreement can be found. Constitutional convention prevents the position of one of the principal actors, the governor general, from ever being known. ${ }^{20}$ Justice Shore held, and the Federal Court of Appeal agreed, that the statements of the actors involved in this case are inconclusive. There is no signed document evidencing any explicit agreement. There is, of course, the unanimously adopted fixed-date election law, but it is too vague to amount to an explicit agreement that would support a workable convention. It says nothing about the prime minister's discretion to advise dissolution, and it does not deal with matters such as the House losing confidence in the government, or the existence of a dysfunctional House, ${ }^{21}$ or even the desire of a prime minister to consult the people because of changed circumstances or the emergence of important national issue. ${ }^{22}$ There is no conclusive evidence that such an explicit agreement ever existed on these points or that the relevant actors ever believed they were bound by such an agreement in this case.

Second, whereas Heard looks to general expectations to establish the existence of a convention, Jennings looks to the reasons why such a convention might exist. The reasons that are required to establish a convention are constitutional, not political, in nature. Political reasons are debating points. They are the plausible arguments that frame each side of a political debate. Arriving at the political reasons that eventually carry the day is a matter of weighing and balancing, a polycentric choice, a political judgment. Constitutional reasons, the only kind of reasons that can justify a constitutional convention, are of a different order. They are a matter of constitutional logic; they are unanswerable. For example, the convention of responsible gov- ernment that requires the executive to maintain the confidence of the House is necessary to the parliamentary form of government. The constitution makes no mention of a cabinet but such a body must be constituted both to organize the legislative agenda of Parliament and to ensure the implementation of laws passed by Parliament. The convention that requires the governor general to assent to all bills duly passed by Parliament is necessary in order to preserve the democratic nature of our constitution. There can be no legitimate doubt, no controversy, on these points. While "general expectations" may be based on the kind of incontrovertible constitutional reasons needed to turn norms into conventions, such expectations may equally be based on nothing more than transient political preferences. These preferences do not amount to the enduring acceptance that a constitutional convention must enjoy.

General expectations with respect to fixed election dates illustrate the point. The debate on this change to electoral rules was, and indeed still is, political. There is no one correct outcome to the debate based on unanswerable constitutional logic. On the one hand, those favouring fixed elections will point to the need to ensure that the governing party has no unfair electoral advantage as a result of its control over the timing of the ballot. On the other hand, those opposed will argue that fixed elections are a republican idea that is fundamentally incompatible with the notion of responsible government in a parliamentary system. They might also argue, citing the democratic principle, that the prime minister must have discretion to consult the electorate at any time on matters of pressing national importance. There no logical right or wrong between these positions that would amount to a constitutional imperative. Rather, there is a legitimate, ongoing political debate.

There is here, too, an overwhelming practical problem. Statements of general expectation rarely amount to the kind of clear and cogent evidence needed to prove the existence of a constitutional convention. The statements are unlikely to reflect a consensus, and the expectations to which they attest are often ephemeral and difficult to discern. The norms described in 
such statements frequently lack the clarity and the precision to be workable as constitutional conventions. For example, statements dealing with the pros and cons of fixed election dates reveal no consensus, nor anything like a general expectation, as to the desirability of fixed election dates. While one can be confident in the existence of general expectations concerning conventions such as responsible government, the existence of general expectations concerning the desirability of fixed election dates is quite another matter.

Third, Jennings and Heard differ as to whose beliefs are determinative in establishing the existence of a constitutional convention. Jennings points to the beliefs of the relevant actors in the constitutional precedents. Heard cites the general expectations of a "larger constitutional community," encompassing constitutional scholars, think-tank experts, and journalists. He criticizes the "insular approach" of considering only the beliefs of the actors exercising constitutional authority. Jennings has this right. The relevant actors in the precedents were the individuals who had the practical responsibility of making the constitution work, who actually made the operative decisions, and who knew that they would have to deal with the immediate consequences of those decisions. Their beliefs as to whether they were bound by a constitutional norm, or rather were exercising a political choice, were beliefs born of their immediate obligations. That might not be determinative except that the actors were also accountable to the electorate for their constitutional decisions. If they failed to honour a convention under the mistaken belief that they were not bound by a constitutional imperative, there would have been a democratic remedy in the ballot box. By placing responsibility for safeguarding constitutional conventions with those actually administering the constitution, the electorate is made the ultimate arbiter of the existence and wisdom of the conventions. There would be no way to hold the "larger constitutional community" to account if its general expectations as to the existence of a convention proved unsound. The larger constitutional community does not have the same degree of responsibility, or indeed any responsibility, for its general expectations.
There are also practical problems in relying on the broader constitutional community to determine if a convention exists. Who is in this privileged constitutional community, and who is out? Of the diverse views in this community - and there will be great diversity - which views win the day and which are dismissed? Do the opinion writers at the Globe and Mail carry more weight than the editorialists at the Regina Leader-Post? Are the views of the constitutional professor with the most Supreme Court of Canada citations to be preferred over those of a professor at the leading law school in the country? Why do constitutional "experts" get to determine which rules amount to conventions - as opposed to, say, members of Parliament, a Senate committee, or a representative panel of ordinary citizens? And, who will hold the chattering constititutional heads to account for their opinions on the existence, or not, of constitutional conventions?

Constitutional change is not to be approached lightly. Theories that would make it easier to prove the existence of conventions are to be treated with caution. In any event, in the Conacher case, the courts have correctly held that the evidentiary record does not support, under any theory, a claim that there exists a constitutional convention restricting the powers of the prime minister to recommend dissolution to the governor general. ${ }^{23}$

\section{Notes}

* Professor of Law, Johnson-Shoyama Graduate School of Public Policy, University of Regina. I am grateful for helpful comments on this article from Dr. Peter Neary, Professor Emeritus, University of Western Ontario.

1 Conacher v. Canada (Prime Minister), 2009 FC 920 (CanLII) [Conacher (FC)].

2 Canada Elections Act, S.C. 2000, c. 9.

3 Conacher v. Canada (Prime Minister), 2010 FCA 131 at para. 12 (CanLII) [Conacher (FCA)].

4 Reference re Resolution to Amend the Constitution, 1981 CanLII 25 (S.C.C.), [1981] 1 S.C.R. 753 at 858 (Laskin, C.J.C. dissenting) [Patriation Reference].

5 Similar language is used to define the term "principles of fundamental justice" found in Section 7 of the Canadian Charter of Rights and Freedoms, 
Schedule B, part I to the Canada Act 1982 (U.K.) 1982, c. 11. See: R. v. Malmo-Levine, 2003 SCC 74, [2003] 3 S.C.R. 571 at para. 113 (CanLII). See R. v. Oakes, 1986 CanLII 46 (S.C.C.), [1986] 1 S.C.R. 103 at para. 68 , and cases cited there, indicating that clear and cogent evidence will be required for proof in constitutional matters.

7 See Eugene A. Forsey and G.C. Eglington, "The Question of Confidence in Responsible Government," study prepared for the Special Committee on the Reform of the House of Commons (Ottawa: 1985), cited in James R. Robertson, "Bill C-16: an Act to Amend the Canada Elections Act" (Legislative Summary 530E), Library of Parliament (29 June 2006, revised 3 May 2007), online: Parliament of Canada <http:// www2.parl.gc.ca/Sites/LOP/LegislativeSummaries/bills_ls.asp?lang=E\&ls=c16\&source $=$ libra ry_prb\&Parl=39\&Ses $=1>$. Forsey and Eglington argue that fixed election dates could be effected only by means of a constitutional amendment. Standing Committee on Procedure and House Affairs, Evidence, 39th Parl., 1st sess., No. 018 (26 September 2006) at 2 (Hon. Rob Nicholson). Section 41 of the Constitution Act, 1982 provides that amendments in relation to "the office of ... the Governor General" can only be made "where authorized by resolution of the Senate and House of Commons and of the legislative assembly of each province."

9 Conacher (FC), supra note 1 (Applicant's Memorandum of Fact and Law at para. 47), online: Centre for Constitutional Studies <http://www. law.ualberta.ca/centres/ccs/uploads/Conacherfactum.pdf $>$.

10 The government of Canada maintained that the fixed election date set by the law was not meant to limit the prime minister's discretion to advise dissolution but was only meant to create a "statutory expectation" of a certain date for future elections without making that expectation legally enforceable. See Conacher (FC), supra note 1 at para 52, citing Respondents' Memorandum of Fact and Law at para. 38, online: Centre for Constitutional Studies < http://www.law.ualberta. $\mathrm{ca} /$ centres/ccs/uploads/1-Governmentfactum. pdf $>$. The Federal Court of Appeal appears to have accepted this position when it held that the law "expresses the will of Parliament but leaves the Prime Minister and the Governor General able to act in the way they did." Conacher (FCA), supra note 3 at para. 9. Note also that Professor Ned Franks said in April 2008 that the fixed-date election law does not limit the prime minister's right to seek dissolution. "PM can override fixed- date vote: expert" Ottawa Citizen (9 April 2008), online: Canada.com < http://www.canada.com/ ottawacitizen/news/story.html?id=15c68d91-edff467f-9045-6f8c44c631d3>.

11 Applicant's Memorandum, supra note 9 at para. 47.

12 Supra note 4.

13 Reference re Objection by Quebec to a Resolution to Amend the Constitution, 1982 CanLII 219 (S.C.C.), [1982] 2 S.C.R. 793 [Quebec Veto Reference].

14 Conacher (FC), supra note 1 at para. 59.

15 Ibid. at para. 37. See also Patriation Reference, supra note 4 at 888 , citing Sir Ivor Jennings, The Law and the Constitution, $5^{\text {th }}$ ed. (London: University of London Press, 1959) at 136.

16 Jennings, ibid.

17 Supra note 13 at 816.

18 Andrew Heard, "Conacher Missed the Mark on Constitutional Conventions and Fixed Election Dates," (2009, in this volume). Shore J. referred to Professor Heard's book, Canadian Constitutional Conventions: The Marriage of Law and Politics (Toronto: University of Toronto Press, 1991) and held that there was insufficient evidence of a new convention even using the "explicit agreement" approach advocated by Heard. Conacher (FC), supra note 1 at para. 44.

19 The 1931 Statute of Westminster, by which the United Kingdom recognized the independence of certain of its former dominions, is frequently cited as an example of a convention brought into existence by way of an explicit agreement. The Statute codified explicit agreements reached by dominion leaders at Imperial Conferences held in 1926 and 1930. What makes dominion independence, as evidenced by the Statute of Westminster, a constitutional convention is not the fact that its source is in an explicit agreement, but rather that this particular explicit agreement, like past precedent, is permanent and irrevocable. Any attempt to revoke the Statute of Westminster would either be ignored by the former dominions (external parties will not examine the internal affairs of another country) or would result in the former dominions unilaterally declaring independence. The principle of independence, like the principle of responsible government, is a constitutional convention not because of its origin but rather because of its binding and permanent character. The Statute of Westminster example, far from representing an alternate method of identifying constitutional conventions, is entirely consistent with the Jennings test. A fixed election agreement, embodied in a domestic law, is subject to reconsideration, 
amendment or revocation in a way that the Statue of Westminster could never be.

20 Conversations between the governor general and the prime minister are strictly privileged. Such a convention insures that the neutrality of the Crown will be preserved and that the prime minister may benefit from the advice of a source whose sole interest is the welfare of the nation.

21 Prime Minister Harper indicated that his reason for calling the September 2008 election was the dysfunctional nature of the Parliament that had been elected in January 2006. He cited the inability of Parliament to function productively, the stalling of government legislation in the opposition-dominated Senate and in the House, and a committee system "increasingly in chaos." See "Harper hints at triggering election," CBC News (14 August 2008), online: CBC. ca $<$ http://www.cbc.ca/canada/new-brunswick/ story/2008/08/14/harper-election.html $>$. Prior to visiting the governor general to request dissolution, the prime minister, who was in a minority situation, met each of the three opposition party leaders separately. Following those meetings, each opposition leader stated that there was "no common ground" between his party and the government with respect to a legislative agenda.

22 The 1988 "free trade" election is an example. Also, see Conacher (FCA), supra note 3 at para. 7.

23 Conacher (FC), supra note 1 at para. 46; Conacher (FCA), supra note 3 at para. 12 . 